\title{
Sosialisas Kewaspadaan Dini Penyakit Demam Berdarah Dengue pada Ibu PKK di Desa Bolon Kecamatan Colomadu Kabupaten Karanganyar
}

\author{
Wartini $^{1}$, Nur Ani ${ }^{2}$, Nine Elissa Maharani ${ }^{3}$ \\ Program Studi Kesehatan Masyarakat, FKM Universitas Veteran Bantara Sukoharjo ${ }^{1,2,3}$ \\ e-mail: wartiniskm.msc@gmail.com ${ }^{1}$, aninurk3@gmail.com ${ }^{2}$
}

\begin{abstract}
ABSTRAK
Desa Bolon merupakan wilayah endemis penyakit demam berdarah dengue, data hasil pemantauan jentik berkala masih ditemukan rumah yang positif jentik. Melalui kader dan ibu PKK harapannya akan tumbuh jumantik mandiri setiap rumah dan dapat mengoptimalkan PSN di rumah masing-masing untuk pecegahan penyakit Demam Berdarah Dengue. Metode yang digunakan dalam pengabdian ini adalah penyuluhan dan memotivasi untuk terbentuknya jumantik mandiri di setiap rumah. Variabel yang diamati yaitu pemahaman PHBS melalui PSN dan terbentuknya jumantik mandiri di setiap rumah tangga. Untuk mengetahui tingkat keberhasilan program melalui pre dan post test. Hasil pre dan pos test diketahui rerata pre sebesar 12,64 dan post test sebesar 17,68 dengan kenaikan pengetahuan sebesar 5,04 (39,87\%) hasil pengetahuan yang baik mengenai penyakit demam berdarah dan pencegahannya dapat menjadi modal utama bagi ibu-ibu PKK untuk melaksanakan kegiatan pemberantasan vector penyebab DBD. Disarankan kepada ibu-ibu PKK dan ibu rumah tangga untuk melakukan PSN secara serentak minimal 1 kali dalam seminggu untuk memutus perkembangbiakan nyamuk menjadi dewasa yang dapat menjadi vektor penular DBD.
\end{abstract}

Kata kunci : Demam Berdarah Dengue, Kader Kesehatan, PKK.

\begin{abstract}
Bolon village is a dengue-endemic area, but the results of periodic larva monitoring find houses that are positive for larvae. Through PKK cadres and mothers, it is hoped that each house will grow independent jumantik and can optimize PSN in their respective homes for the prevention of Dengue Hemorrhagic Fever. The method used in this service is counseling and motivation for the formation of independent jumantik in each house. The variables observed were the understanding of PHBS through PSN and the formation of independent jumantik in each household. To determine the success rate of the program through pre and post-tests.

The pre-test and post-test results mean that the pre-test is 12.64, and the post-test results are 17.68, with an increase in knowledge of 5.04 (39.87\%), the results of useful knowledge about DHF and its prevention can be the main ones for mothers. PKK will carry out activities to eradicate the vector that causes DHF. It is recommended for PKK mothers and homemakers to carry out PSN simultaneously at least once a week to break down the breeding of mosquitoes into adults, which can become vectors of dengue transmission.
\end{abstract}

Keywords: Dengue Hemorrhagic Fever, Health Cadres, PKK.

\section{PENDAHULUAN}

Penyakit Demam Berdarah Dengue (DBD) adalah penyakit menular yang disebabkan oleh virus dengue dan ditularkan melalui gigitan nyamuk Aedes aegypti dan Aedes albopictus yang hidup di dalam dan di sekitar rumah. Nyamuk Aedes betina terinfeksi virus dengue pada saat dia menghisap darah dari seseorang yang sedang dalam fase demam akut yaitu 2 hari sebelum panas sampai 5 hari setelah demam timbul. Nyamuk menjadi infektif 8-12 hari sesudah menghisap darah penderita yang sedang dalam fase demam akut. Penyakit ini ditandai dengan panas (demam) dan disertai dengan pendarahan (Kemenkes RI, 2012). 
Berdasarkan data Riskesdas (2018) proporsi Pemberantasan Sarang Nyamuk (PSN) yang dilakukan rumah tangga rata-rata di Indonesia $(31,2 \%)$ dengan rata-rata sebaran di area perkotaan sebesar 32,7\% dan di pedesaan sebesar 29,4\%. Kejadian penyakit demam berdarah dengue (DBD) per 1 Februari 2019 tercatat 15.132 kasus dengan angka kematian mencapai 145 jiwa di seluruh Indonesia. Direktur Penyakit Tular Vektor dan Zoonotik Kementerian Kesehatan (Kemenkes), Siti Nadia Tarmizi mengungkapkan, provinsi dengan kasus DBD dan kematian akibat DBD paling tinggi saat ini adalah Provinsi Jawa Timur dengan 3.074 kasus dan 52 kematian. Selanjutnya, posisi kedua ditempati Jawa Barat dengan 2.204 kasus dan 14 meninggal dunia, lalu disusul Nusa Tenggara Timur (NTT) dengan 1.092 kasus dan 13 meninggal dunia, serta; Sumatera Utara dengan 1.071 kasus dan 13 meninggal dunia (inews.id, 2019).

Berdasarkan data Puskesmas Colomadu, Desa Bolon terdiri dari 6 dusun yaitu Dusun Bolon, Dusun Gonggangan, Dusun Tempuran, Dusun Madoh, Dusun Pucung, dan dusun Jetak. Jumlah penduduk Desa Bolon sebanyak 6535 jiwa, dan yang terpadat adalah Dusun Jetak dengan jumlah penduduk sebanyak 1777 jiwa. Menurut data puskesmas Desa Bolon terdapat 7 kasus yang merupakan wilayah tertinggi kedua setelah Kecamatan Karanganyar. Hal ini dikarenakan masih adanya masyarakat yang tidak memahami pentingnya melakukan pemberantasan sarang nyamuk secara berkala walaupun telah dilakukan pemantauan jentik secara berkala oleh kader kesehatan. Kader kesehatan dan juru pemantau jentik Dusun Gonggangan melakukan pemantauan secara berkala satu bulan sekali, namun upaya tersebut belum memberikan kesadaran masyarakat akan pentingnya pemberantasan sarang nyamuk. Hal ini terbukti masih banyak ditemukan rumah dengan positif jentik nyamuk. Kinerja kader tidak akan efektif jika tidak dibarengi dengan usaha bersama ibu rumah tangga dalam melakukan Pemberantasan sarang nyamuk (Puskesmas Desa Bolon, 2020).

Salah satu tugas kader kesehatan di Desa Bolon adalah melakukan kunjungan ke rumahrumah warga terkait pemantauan jentik yang dilakukan secara rutin setiap bulan sekali, namun karena belum adanya konsekuensi hukuman bagi masyarakat yang dalam pemantauan jentik terdapat jentik, maka masyarakat masih enggan melakukan PSN dengan alasan sayang kalau airnya dibuang. Hal inilah yang menjadi penyebab adanya rumah yang positif jentik. Salah satu program pokok PKK adalah kesehatan dan perencanaan sehat, sehingga penting bagi ibu PKK memahami pentingnya menjaga lingkungan, kesehatan dan pencegahan terhadap berbagai penyakit dalam keluarganya. Ibu PKK di Dusun Gonggangan memiliki anggota bervariasi dari yang berumur muda sampai lansia, sehingga keragaman pengetahuan dan pola pikir masing-masing perlu diluruskan terkait pentingnya melakukan PSN sebagai upaya pencegahan penyakit DBD. Hasil survey pada Ibu kader kesehatan dan PKK di Dusun Gonggangan Desa Bolon Kecamatan Colomadu dan berdasarkan data Puskesmas Colomadu : 
1. Perilaku hidup bersih dan sehat masih rendah

Indikator PHBS salah satunya adalah pengelolaan sampah rumah tangga. Pengelolaan sampah yang kurang baik akan berpengaruh pada kesehatan masyarakat di sekitarnya. Pembuangan sampah yang hanya dibuang di saluran air, sungai dan di kebun perlu mendapatkan perhatian terutama jika sampah yang dibuang dapat menjadi tempat perkembangan biakan vector penyakit misalnya Aedes Agipty. Dusun Gonggangan rata-rata ibu rumah tangga membuang sampahnya di kebun belakang rumah secara terbuka, dan selama ini belum ada upaya pemilahan sampah secara mandiri oleh ibu rumah tangga, sehingga sangat memungkinkan sampah-sampah yang dibuang sebagai tempat perindukan nyamuk Aedis Aegipty selain tempat penampungan air yang mereka gunakan. Hal ini terjadi karena pengetahuan dan praktik masih rendah tentang PHBS. Pengetahuan dan praktik PHBS yang rendah disebabkan karena berbagai hal diantaranya pengetahuan yang masih rendah, tidak adanya transfer pengetahuan dari tenaga kesehatan ke masyarakat. Dengan adanya peningkatan kapasitas kader dan ibu PKK diharapkan dapat meningkatkan pengetahuan dan praktik PHBS, dan selanjutnya dapat melakukan upaya pencegahan penyakit DBD secara mandiri melalui menjaga kebersihan rumah dan lingkungan sekitarnya sehingga keluarga dan masyarakat sehat.

2. Masih terdapat rumah yang positif jentik

Masih tingginya rumah yang dipantau positif jentik yang merupakan indikasi bahwa praktik pemberantasan sarang nyamuk belum diterapkan semua rumah tangga, praktik PSN yang rendah ini ada berbagai faktor penyebab diantaranya pengetahuan mengenai tempat perindukan nyamuk dan cara pencegahan penyakit DBD pada masyarakat. Selain itu berdasarkan data dari Desa (satgas penangulangan penyakit DBD) terdapat 1 penderita positif DBD selama bulan Januari-Maret 2020. Hal ini terjadi karena tidak ada transfer pengetahuan dan pemahaman dari kader jumantik kepada masyarakat. Kader hanya bertugas untuk memeriksa jentik tanpa melakukan upaya promosi kesehatan kepada pemilik rumah yang positif jentik karena minimnya pengetahuan mereka terkait pentingnya PSN dan pengelolaan sampah yang baik. Melalui transfer pengetahuan dari tenaga kesehatan kepada kader kesehatan dan ibu anggota PKK, diharapkan dengan pengetahuan dan pemahaman yang baik mengenai pentingnya kebersihan lingkungan dan pengelolaan sampah yang baik diharapkan masyarakat terhindar dari penyakit demam berdarah dengue.

Penyakit demam berdarah dengue merupakan penyakit endemis di wilayah Colomadu dan Desa Bolon karena merupakan wilayah dengan kepadatan penduduk tinggi, mengingat wilayah Colomadu khususnya Desa Bolon merupakan wilayah pengembangan perumahan sehingga banyak pendatang dan pembangunan selokan yang tidak mengalir dengan baik akan menjadi tempat 
perkembangan biakan vector penyakit demam berdarah. Hasil survey data penyakit demam berdarah pada tahun 2019 merupakan penyumbang terbesar kedua setelah Karanganyar. Hal ini dapat dicegah dengan melakukan upaya pemberantasan sarang nyamuk dengam metode $3 \mathrm{M}$ plus yaitu menguras, mengubur, dan menutup barang/sampah yang dapat dijadikan tempat perindukan plus menggunakan obat anti nyamuk dan kelambu, dll. Berdasarkan permasalahan yang ada, maka penulis membuat program pengabdian masyarakat dengan judul "Sosialisasi Kewaspadaan Dini Penyakit Demam Berdarah Dengue Pada Ibu Pkk Di Desa Bolon Kecamatan Colomadu Kabupaten Karanganyar".

Tujuan kegiatan pengabdian masyarakat ini adalah untuk meningkatkan pengetahuan dan kewaspadaan dini bahaya penyakit demam berdarah dengue sehingga peduli terhadap lingkungan sekitar dengan melakukan pemberantasan tempat-tempat yang dapat dijadikan tempat perindukan nyamuk Aedes Agypti yang merupakan vector penyakit demam berdarah. Upaya ini dilakukan agar masyarakat melakukan kegiatan pemberantasan sarang nyamuk melalui kegiatan $3 \mathrm{M}$ (menutup, menguras, dan mengubur barang/ tempat yang dapat dijadikan sebagai perindukan nyamuk Aedes Aegypti). Sasaran dalam pengabdian masyarakat ini adalah Ibu PKK di Dusun Gonggangan bertujuan agar setiap ibu memiliki kepedulian terhadap rumah tangga dan sekitarnya dengan harapan mampu menjadi juru pemantau jentik untuk rumahtangganya sendiri dan rumah tangga di sekitar rumahnya. Hal ini bertujuan untuk menjaga keluarga dan tetangganya dari vektor demam berdarah dengue. Selain itu, ibu-ibu PKK Dusun Gonggangan diharapkan melakukan pemberantasan sarang nyamuk secara rutin minimal satu minggu sekali untuk memutus pertumbuhan nyamuk dewasa. Oleh sebab itu, sasaran utama kegiatan pengabdian masyarakat ini adalah ibu PKK yang notabenya menjadi ibu rumah tangga yang bertanggungjawab terhadap kebersihan rumah dan kesehatan keluarganya.

\section{METODE}

Kegiatan pengabdian masyarakat Sosialisasi Kewaspadaan Dini Penyakit Demam Berdarah Dengue telah dilaksanakan pada tanggal 8-13 September 2020 oleh tim PMKBI. Kegiatan ini tidak hanya memberikan penyuluhan kepada mitra, tetapi juga melibatkan mitra untuk bisa berperan secara aktif dalam kegiatan yang telah dilaksanakan. Tim PKMBI sebagai fasilitator dan mitra yang diberdayakan bisa bekerjasama dan bersinergi bersama untuk mewujudkan kemandirian kesehatan bagi mitra dan bersinergi dengan pemerintah untuk pencegahan penyaki DBD. Sesuai dengan permasalahan prioritas dan solusi yang ditawarkan, maka rencana kegiatan yaitu ;

(1) Melakukan penyuluhan kepada kader kesehatan dan Ibu PKK tentang pentingnya PSN,

(2)Pembentukan jumatik di setiap rumah tangga Dusun Gonggangan Desa Bolon Kecamatan Colomadu. 
1. Sosialisasi Pemberantasan sarang nyamuk (PSN)

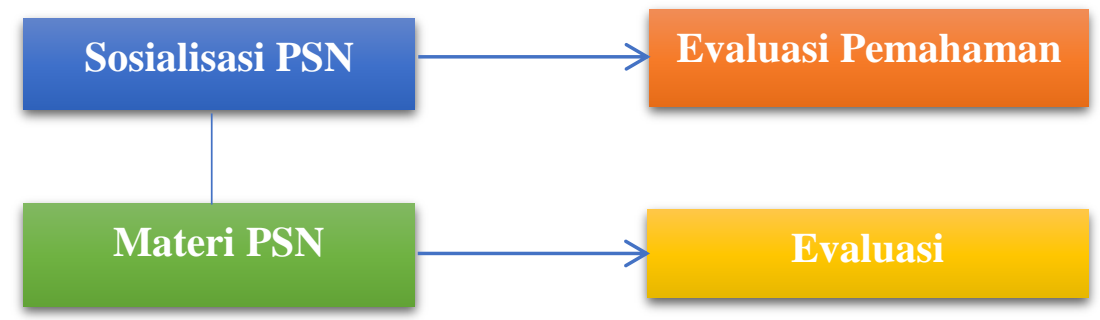

Gambar 1. Alur kegiatan Sosialisasi PSN kader kesehatan dan Ibu PKK Dusun Gonggangan Desa Bolon, Kecamatan Colomadu, Kabupaten Karanganyar

Peserta : Ibu kader dan ibu-ibu PKK sebanyak 28 orang Dusun Gonggangan

Metode : Ceramah tentang perilaku hidup bersih dan sehat skala rumah tangga selama 30 menit, dilanjutkan diskusi 15 menit.

Evaluasi : sebelum dan sesudah materi penyuluhan, seluruh peserta diberi daftar pertanyaan untuk mengetahui Tingkat pemahaman peserta tentang PSN. Pertanyaan pretes dan postes dibuat di google form dengan model jawaban pilihan ganda dengan memilih satu jawaban yang paling tepat.

Nilai peserta $=($ jumlah jawaban benar $) /($ jumlah soal $) \times 100$

Indikator Keberhasilan penyuluhan ditentukan dari nilai jawaban soal tingkat pemahaman adanya peningkatan nilai peserta antara pre dan post test. Nilai post test $>60$.

\section{Pembentukan jumantik tingkat rumah tangga}

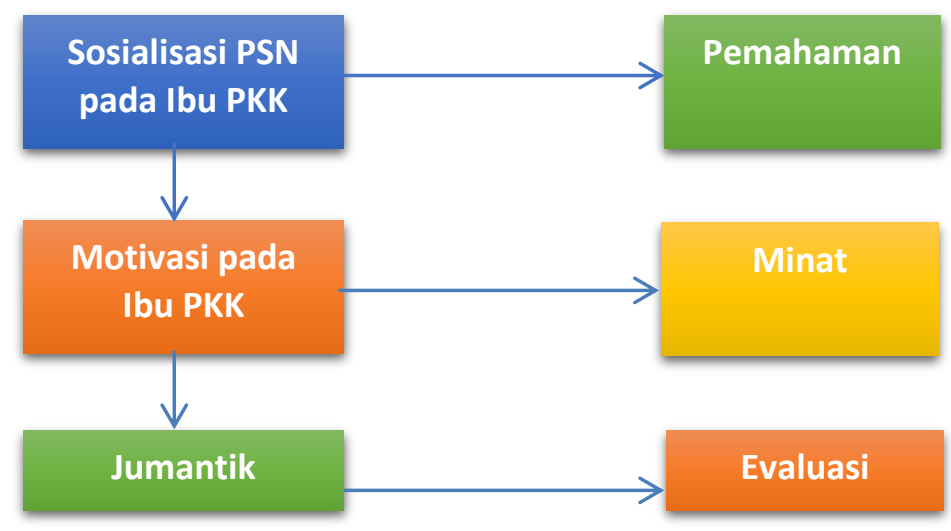

Gambar 2. Alur kegiatan pembentukan jumantik pada ibu PKK Dusun Gonggangan Desa Bolon, Kecamatan Colomadu Kabupaten Karanganyar

Peserta : Kader dan Ibu-ibu PKK Dusun Gonggangan sebanyak 28 orang.

Metode : ceramah dan praktik/simulasi PSN dilakukan melalui video rekaman yang kemudian disebarkan oleh kader ke group WA ibu-ibu PKK 
Evaluasi : semua peserta diberi daftar pertanyaan melalui googleform guna mengetahui pemahaman dan minat peserta dalam program pembentukan jumantik. Model pertanyaan berupa pertanyaan tertutup dengan pilihan ganda sehingga peserta tinggal memilih pilihan jawaban yang sesuai.

Nilai peserta : Jumlah jawaban benar/jumlah soal x 100

Keberhasilan pembentukan jumantik mandiri ditentukan pemahaman peserta tentang penyakit DBD dan cara pencegahannya sebesar 60\% benar serta motivasi para ibu PKK.

\section{HASIL DAN PEMBAHASAN}

Pengabdian kepada masyarakat yakni sosialisasi kewaspadaan dini penyakit demam berdarah dengue telah dilaksanakan pada tanggal 8-13 September 2020 secara daring melalui group Wathsap ibu-ibu di Desa Bolon Kecamatan Colomadu Kabupaten Karanganyar. Acara berjalan dengan lancar dan ibu PKK yang berpartisipasi dalam mengembalikan pretest dan posttes sebanyak 28 orang. Berikut adalah sampel foto saat kegiatan berlangsung;

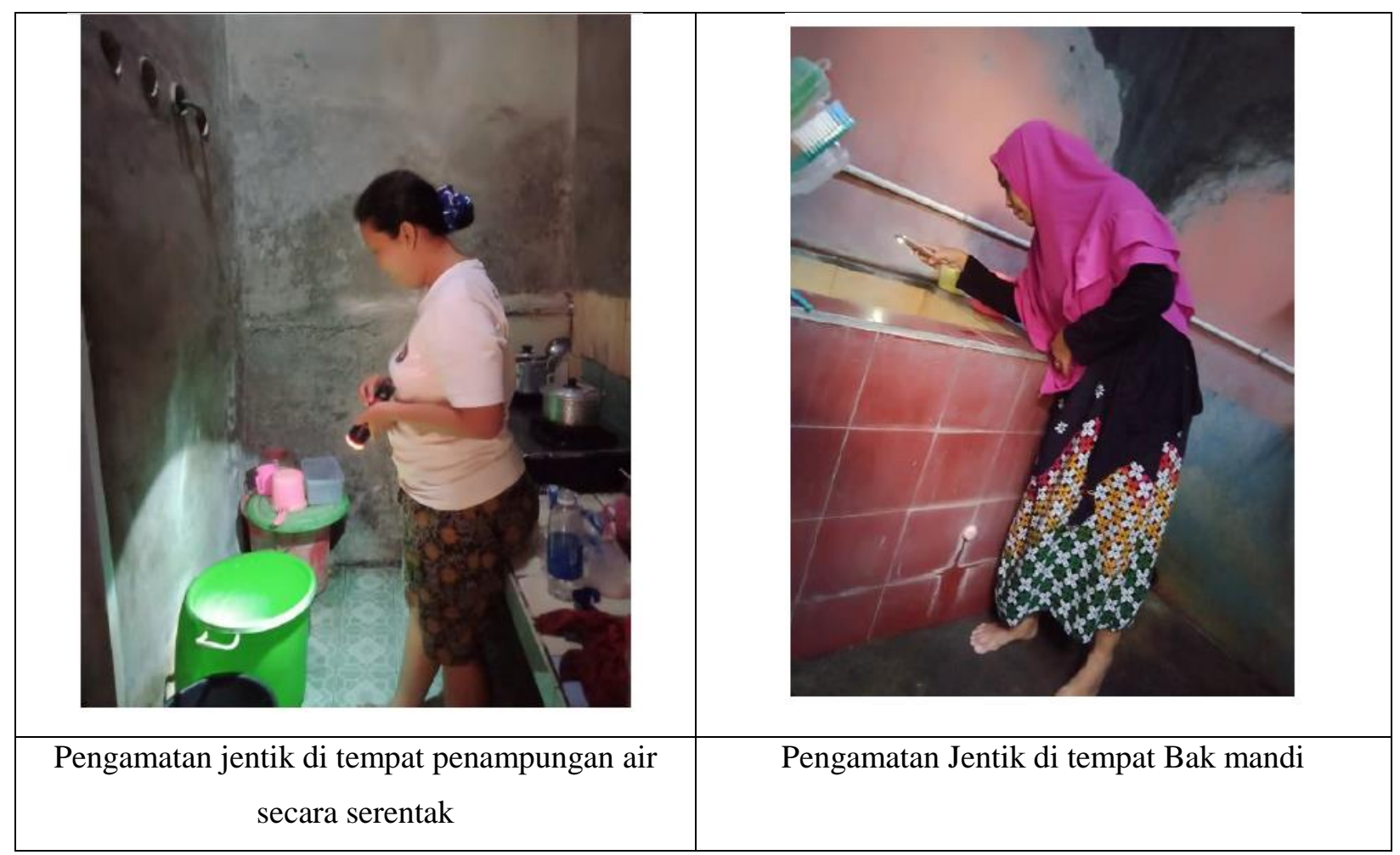


Adapun untuk hasil kegiatan pengabdian dapat digambarkan dalam tabel berikut ini ;

Table 1. Karakteristik Ibu PKK

Desa Bolon Kecamatan Colomadu Kabupaten Karanganyar

\begin{tabular}{ccccc}
\hline \multirow{2}{*}{ Variabel } & $\mathbf{n}$ & \multicolumn{3}{c}{ Nilai } \\
\cline { 3 - 5 } & & Min & Max & Mean \\
\hline Umur & 28 & 21 & 50 & 36,32 \\
Pendidikan & 28 & SMP/Sederajat & SMU & \\
\hline
\end{tabular}

Sumber : Olah Data Primer (2020)

Berdasarkan tabel 1 diatas dapat diketahui usia minimum peserta yang mengikuti ada di usia 21 tahun dan usia tertinggi di usia 28 tahun. Sedangkan pendidikan terendah SMP/sederajat dan tertinggi adalah SMA.

Table 2. Hasil Pre Dan Post Test Ibu PKK Desa Bolon Kecamatan Colomadu Kabupaten Karanganyar

\begin{tabular}{ccccc}
\hline \multirow{2}{*}{ Variable } & \multirow{2}{*}{} & \multicolumn{3}{c}{ Nilai } \\
\cline { 3 - 5 } & & Min & Max & Mean \\
\hline Pretest & 28 & 50 & 83,3 & 70,24 \\
Posttes & 28 & 88,89 & 100 & 98,21 \\
Selisih pre & 28 & 16,67 & 38,89 & 27,98 \\
dan post & \multicolumn{4}{l}{} \\
\hline \multicolumn{2}{l}{ Prosentase kenaikan pengetahuan ibu PKK $=27,98 / 16,67 * 100 \%=39,83 \%$} \\
\hline
\end{tabular}

Sumber : Olah Data Primer (2020)

Berdasarkan tabel 2 diketahui bahwa hasil pretest dan posttest ibu-ibu PKK Desa Bolon Kecamatan Colomadu nilai pretest paling rendah 50 dan paling tinggi 83,3 hal ini menunjukkan bahwa sebenarnya sudah memahami melakukan pemberantasan sarang nyamuk sebagai upaya kewapadaan dini terhadap vektor DBD. Setelah dilakukan sosialisasi terhadap kewaspadaan dini penyakit DBD pengetahuan meningkat dengan nilai minimal 88,89 dan nilai maksimal 100 dengan rerata kenaikan 27,98 (39,83\%). Kenaikan pengetahuan ibu-ibu PKK terkait kewapadaan dini penyakit DBD masih jauh dari target yaitu naik $60 \%$. Hal ini disebabkan karena instrumen sangat sederhana dan dengan model online maka informasi yang ingin didapat secara mudah diakses dengan android yang dimiliki untuk menjawab karena waktu yang cukup lama untuk menunggu responden mengirimkan jawaban ke sistem yang telah ditentukan. Selain itu, jika dilihat dari umur dan pendidikan responden yang relatif masih muda memungkinkan untuk mencari informasi sesuai dengan kebutuhannya melalui teknologi yang berkembang saat ini. Hampir rerata ibu-ibu PKK memiliki HP android sehingga memungkinkan memanfaatkan teknologi tersebut untuk mencari informasi sesuai yang dibutuhkan.

Media yang digunakan oleh penulis dalam pengabdian ini adalah video yang memiliki suara untuk menjelaskan materi sosialisasi sehingga memudahkan para Ibu-Ibu PKK untuk memahami isi dari materi yang disampaikan. Hal ini sesuai dengan teori perilaku bahwa pengenalan objek terjadi melalui pengamatan dan penginderaan (telinga, mata, hidung dII) terhadap stimulus dan stimulus akan diolah 
menjadi informasi terhadap objek tersebut (Forum Promosi Kesehatan Nasional, 2018). Hal ini sesuai dengan penelitian Alini dan indrawati (2018) yang menyatakan terdapat perbedaan pengetahuan setelah dilakukan promosi kesehatan dan penggunaan media audiovisual lebih efektif untuk meningkatkan pengetahuan daripada media leaflet.

Ibu-ibu PKK telah memahami bahwa penyakit DBD dapat dicegah penularannya dengan melakukan pemberantasan sarang nyamuk. Cara yang dapat dilakukan saat ini dengan menghindari atau mencegah gigitan nyamuk penular DBD. Oleh karena itu, upaya pengendalian DBD yang penting pada saat ini adalah melalui upaya pengendalian nyamuk penular dan upaya membatasi kematian karena DBD. Atas dasar itu, maka upaya pengendalian DBD memerlukan kerjasama dengan program dan sektor terkait serta peran serta masyarakat (Kemenkes, 2017).

Upaya pemberantasan penyakit demam berdarah dengue dilaksanakan dengan cara tepat guna oleh pemerintah dengan peran serta masyarakat yang meliputi :

(1) pencegahan,

(2) penemuan, pertolongan dan pelaporan,

(3) penyelidikan epidemiologi dan pengamatan penyakit demam berdarah dengue,

(4) penanggulangan seperlunya,

(5) penanggulangan lain dan

(6) penyuluhan.

Pencegahan dilaksanakan oleh masyarakat di rumah dan Tempat umum dengan melakukan pemberantasan sarang Nyamuk (PSN) yang meliputi:

a). menguras tempat penampungan air sekurang-kurangnya seminggu sekali, atau menutupnya rapat-rapat.

b). Mengubur barang bekas yang dapat menampung air

c). Menaburkan racun pembasmi jentik (abatisasi)

d). Memelihara ikan

e). Cara-cara lain membasmi jentik (Kemenkes, 2011).

Penyebab penyakit Dengue adalah Arthrophod borne virus, famili Flaviviridae, genus flavivirus.Virus berukuran kecil $(50 \mathrm{~nm})$ ini memiliki single standard RNA. Virion-nya terdiri dari nucleocapsid dengan bentuk kubus simetris dan terbungkus dalam amplop lipoprotein. Genome (rangkaian kromosom) virus Dengue berukuran panjang sekitar 11.000 dan terbentuk dari tiga gen protein struktural yaitu nucleocapsid atau protein core (C), membrane-associated protein (M) dan suatu protein envelope (E) serta gen protein non struktural (NS). Terdapat empat serotipe virus yang dikenal yakni DEN-1, DEN-2, DEN-3 dan DEN-4. Ke-empat serotipe virus ini telah ditemukan di berbagai wilayah Indonesia. Hasil penelitian di Indonesia menunjukkan bahwa Dengue-3 sangat 
berkaitan dengan kasus DBD berat dan merupakan serotipe yang paling luas distribusinya disusul oleh Dengue-2, Dengue-1 dan Dengue -4 (Kemenkes, 2011).

Habitat perkembangbiakan Aedes sp. ialah tempat-tempat yang dapat menampung air di dalam, di luar atau sekitar rumah serta tempat-tempat umum. Habitat perkembangbiakan nyamuk Aedes aegypti dapat dikelompokkan sebagai berikut: 1) Tempat penampungan air (TPA) untuk keperluan sehari-hari, seperti: drum, tangki reservoir, tempayan, bak mandi/wc, dan ember. 2)Tempat penampungan air bukan untuk keperluan sehari-hari seperti: tempat minum burung, vas bunga, perangkap semut, bak kontrol pembuangan air, tempat pembuangan air kulkas/ dispenser, talang air yang tersumbat, barang-barang bekas (contoh : ban, kaleng, botol, plastik, dII). 3)Tempat penampungan air alamiah seperti: lubang pohon, lubang batu, pelepah daun, tempurung kelapa, pelepah pisang dan potongan bambu dan tempurung coklat/karet, dll. (Kemenkes, 2017)

Beberapa faktor yang berisiko terjadinya penularan dan semakin berkembangnya penyakit DBD adalah pertumbuhan jumlah penduduk yang tidak memiliki pola tertentu, faktor urbanisasi yang tidak berencana dan terkontrol dengan baik, semakin majunya sistem transportasi sehingga mobilisasi penduduk sangat mudah, sistem pengelolaan limbah dan penyediaan air bersih yang tidak memadai, berkembangnya penyebaran dan kepadatan nyamuk, kurangnya sistem pengendalian nyamuk yang efektif, serta melemahnya struktur kesehatan masyarakat. Selain faktor- faktor lingkungan tersebut diatas status imunologi seseorang, strain virus/serotipe virus yang menginfeksi, usia dan riwayat genetik juga berpengaruh terhadap penularan penyakit (Kemenkes, 2011).

Perubahan iklim (climate change) global yang menyebabkan kenaikan rata-rata temperatur, perubahan pola musim hujan dan kemarau juga disinyalir menyebabkan risiko terhadap penularan DBD bahkan berisiko terhadap munculnya KLB DBD. Sebagai contoh adanya kenaikan Index Curah Hujan (ICH) selalu diikuti dengan kenaikan kasus DBD. Upaya pemberantasan DBD hanya dapat berhasil apabila seluruh masyarakat berperan secara aktif dalam PSN 3M Plus. Gerakan PSN 3M Plus merupakan bagian yang paling penting dari keseluruhan upaya pemberantasan DBD oleh keluarga/ masyarakat. Pengalaman beberapa negara menunjukkan bahwa pemberantasan jentik melalui kegiatan PSN dapat mengendalikan populasi nyamuk Aedes, sehingga penularan DBD dapat dicegah atau dikurangi. Bentuk pelaksanaan kegiatan PSN 3M Plus disesuaikan dengan situasi dan kondisi masingmasing daerah (kearifan lokal). Pembinaan peran serta masyarakat dalam PSN 3M Plus antara lain dapat dikoordinasikan oleh kelompok kerja (Pokja) DBD kelurahan/desa dan kelompok kerja operasional (Pokjanal) DBD kecamatan, kabupaten/kota dan provinsi (Kemenkes, 2017) 


\section{KESIMPULAN}

Kegiatan pengabdian masyarakat ini diperoleh kesimpulan rata-rata umur responden adalah 36, 32 tahun dengan pendidikan sebagian besar adalah sekolah menengah umum/ sederajat. Rerata hasil pre test ibu PKK terkait pengetahuan mengenai DBD sebesar 12,64 dan post test sebesar 17,68 dengan kenaikan pengetahuan sebesar $39.87 \%$.

\section{UCAPAN TERIMA KASIH}

Pertama Penulis mengucapkan terima kasih kepada pihak yang telah memberi dukungan dana pelaksanaan pengabdian masyarakat yaitu LPPM Universitas Veteran Bangun Nusantara yang telah mensupport pendanaan dalam kegiatan ini. Tak lupa pula kami ucapkan terimakasih kepada Dekan FKM dan Kaprodi Kesmas FKM Univet Bantara Sukoharjo.

\section{DAFTAR REFERENSI}

Alini dan Indrawati.2018. Efektifitas promosi kesehatan melalui audiovisual dan leaflet tentang SADARI terhadap peningkatan pengetahuan remaja putri tentang SADARI di SMAN 1 Kampar. Jurnal Ners. Vol 2 No 2.hal 1-9

Dinas Kesehatan Kabupaten Karanganyar. 2019. Profil kesehatan tahun 2018. Karanganyar.

Forum Promosi Kesehatan Nasional. 2018. Dasar Promosi Kesehatan. FKM Undip press. Semarang. Kemenkes RI. 2017. Pedoman Pencegahan dan Pengendalian Penyakit Demam Berdarah Dengue di Indonesia. Dirjen Pengendalian Penyakit dan Penyehatan Lingkungan. Jakarta.

Kemenkes RI. 2011. Modul Pengendalian Demam Berdarah Dengue. Dirjen Pengendalian penyakit dan penyehatan lingkungan. Jakarta.

Kemenkes RI. 2018. Laporan Hasil Riskesdas 2018. Jakarta.

Kemenkes RI. 2019. Kemenkes: Per 1 Februari 2019, Ada 15.132 Kasus DBD di Indonesia. https://www.inews.id/news/nasional/kemenkes-per-1-februari-2019-ada-15-132-kasus-dbd-diindonesia. Diunduh 6 November 2020.

Puskesmas Desa Bolon. 2020. Data Puskesmas Laporan penderita DBD tahun 2020. Desa Bolon. Rina Tri Agustini. 2015. Evaluasi Pemeriksaan Jentik Berkala Rumah Warga Di Wilayah Puskesmas Tanah Kalikedinding Surabaya. Fakultas Kesehatan Masyarakat, Universitas Airlangga, Surabaya https://e-journal.unair.ac.id/PROMKES/article/view/4467/3028 